\title{
KARAKTERISASI ENZIM KITOSANASE DARI BAKTERI KITINOLITIK T5a1 YANG DIISOLASI DARI TERASI
}

\author{
Dewi Seswita Zilda"), Yusro Nuri Fawzya") dan Ekowati Chasanah")
}

\begin{abstract}
ABSTRAK
Bakteri kitinolitik yang mendegradasi kitin dan turunannya telah banyak diisolasi dari berbagai sumber seperti tanah, spons dan limbah udang dan rajungan. Sumber lain yang diduga potensial untuk isolasi bakteri kitinolitik adalah terasi yang merupakan produk fermentasi berbahan baku rebon. Kitosanase adalah enzim kitinolitik yang terlibat dalam produksi kitooligosakarida yang lebih larut air dan berguna dalam berbagai bidang seperti nutrasetikal, medik, dan farmasi. Isolat T5a1, salah satu isolat kitinolitik yang diisolasi dari terasi, ditumbuhkan pada medium minimal sintetik (MSM) dengan penambahan $0,5 \%$ koloidal kitin pada $37^{\circ} \mathrm{C}, 100 \mathrm{rpm}$, di inkubator goyang selama 24 jam untuk produksi kitosanase. Enzim kasar kemudian dipekatkan menggunakan amonium sulfat dan didialisis. Dari hasil karakterisasi, diketahui $\mathrm{pH}$ dan suhu optimum aktivitas enzim adalah 7 dan $50^{\circ} \mathrm{C}$. Enzim stabil pada suhu $40^{\circ} \mathrm{C}$ selama lebih dari 200 menit. Penambahan ion $\mathrm{Mg}^{2+}$ dan $\mathrm{Zn}^{2+}$ menurunkan aktivitas enzim sampai $15 \%$ sementara penambahan ion $\mathrm{Ca}^{2+}$ meningkatkan aktivitas enzim sampai $37 \%$.
\end{abstract}

\begin{abstract}
Characterization of chitosanase from chitinolytic bacteria T5a1 isolated from terasi. By: Dewi Seswita Zilda, Yusro Nuri Fawzya and Ekowati Chasanah

Chitinolytic bacteria have been isolated from many sources such as soil, sponge and waste of shrimp and crab. An alternative source of chitinolytic bacteria is terasi which is a fermented product of krill . Chitosanase, a chitinolytic enzyme involved in chitooligosaccharide production, that is water soluble and useful in various applications, including nutraceutical, medical, and pharmaceutical. A selected isolate, named as T5a1, was grown in a minimum synthetic medium (MSM) added with $0.5 \%$ colloidal chitin at $37^{\circ} \mathrm{C}, 100 \mathrm{rpm}$ for 24 hours using water bath shaker. The crude enzyme produced was concentrated through ammonium sulphate precipitation followed by dialysis and characterization. The result showed that the optimum $\mathrm{pH}$ and temperature of the enzyme were 7 and $50^{\circ} \mathrm{C}$ respectively. The enzyme was considered stable at $40^{\circ} \mathrm{C}$ for over than 200 minutes. Addition of $\mathrm{Mg}^{2+}$ and $\mathrm{Zn}^{2+}$ ions decreased enzyme activity to $15 \%$ and $\mathrm{Ca}^{2+}$ ion increased to $37 \%$.
\end{abstract}

KEYWORDS: chitosanase, chitinolytic bacteria, enzyme characterization

\section{PENDAHULUAN}

Kitosan mempunyai nilai yang tinggi sebagai bahan baku untuk produksi oligomer kitosan yang dilaporkan dapat berfungsi sebagai penghambat pertumbuhan bakteri dan jamur (Kendra \& Hadwiger, 1984; Tokoro et al., 1988; Hadwiger et al., 1994; Shahidi et al., 1999; Kim et al., 2002), chemopreventive yang potensial (Nam et al., 2000), penghambat sel kanker (Jeong et al., 2000) dan sebagai antitumor (Nam et al., 1999; Jeon \& Kim, 2000).

Proses kimiawi dan enzimatis telah digunakan untuk memproduksi kitosan oligomer. Hidrolisis asam pada kitosan menghasilkan berbagai oligosakarida yang tidak spesifik (Bosso et al., 1986). Alternatif proses secara enzimatis untuk memproduksi kitosan oligomer menggunakan kitosanase telah dilaporkan oleh Hirano (1988). Kitosan oligomer yang dihasilkan adalah dimer sampai heptamer. Proses enzimatis lebih disukai karena ramah lingkungan, hasilnya lebih seragam dan menghasilkan oligomer dengan derajat polimerisasi (DP) yang tinggi seperti pentamer sampai heksamer (Kendra \& Kim, 1998).

Kitosanase (EC 3.2.1.132) dapat diproduksi oleh berbagai mikroorganisme seperti kapang, actinomycetes, dan bakteri. Mereka umumnya adalah enzim endo splitting dan dapat menghidrolisis kitosan menjadi kitooligosakarida dan glukosamin. Kemampuan untuk menghidrolisis ikatan bglukosaminidat (GlcN) dan N-acetyl-b-glukosaminidat (GIcNAc) pada kitosan berbeda pada tingkat deasetilasi tergantung pada jenis mikroorganisme penghasil kitosanase (Chiang et al., 2002).

Kitosanase yang berasal dari mikroorganisme mendapatkan perhatian yang khusus karena penting

\footnotetext{
*) Peneliti pada Balai Besar Riset Pengolahan Produk dan Bioteknologi Kelautan dan Perikanan
} 
dalam pengaturan keseimbangan lingkungan, daur ulang biomaterial kitin, preparasi enzimatis kitooligosakarida biofungsional, dan untuk kontrol biologi kapang patogen pada tanaman (Kendra et al., 1989). Beberapa mikroba penghasil kitosanase di antaranya adalah Myxobacter (Hedges \& Wolfe, 1974), Penicillium (Fenton \& Eveleigh, 1981), Nocardia (Sakai et al., 1991), Pseudomonas (Yoshihara et al., 1992), Streptomyces (Bocher et al., 1992), Mucor (Alfonso et al., 1992), Fusarium (Shimosaka et al.,1993), Enterobacter (Yamasaki et al., 1993), Amycolatopsis, Rhodorotula (Shomasekar \& Joseph, 1996) Trichoderma (Nogawa et al., 1998), Matsuebacter (Park et al., 1999), Bacillus (Kurakake et al., 2000; Omumasaba et al., 2000), Burkholderia (Shimosaka et al., 2000), dan Aspergillus (Cheng \& Li, 2000).

Dalam rangka mendapatkan kitosanase baru yang bisa digunakan untuk produksi oligomer kitosan skala besar, skrining bakteri dari berbagai sumber telah dilakukan. Beberapa sumber kitinolitik bakteri yang pernah diteliti adalah udang (Putro, 1982), tanah (Zhu et al., 2003; Choi et al., 2004), air laut dan sedimen sumber air panas (Chasanah, 2004) serta spons (Uria \& Chasanah, 2005). Sumber lainnya yang potensial sebagai sumber bakteri kitinolitik adalah terasi. Bahan bakunya yang berupa jebret (udang kecil atau yang lebih dikenal dengan rebon) banyak mengandung kitin. Salah satu isolat potensial hasil skrining adalah T5a1 (Zilda \& Chasanah, 2005) yang akan dikarakterisasi untuk aplikasi lebih lanjut.

Dalam penelitian ini akan dilakukan karakterisasi khitosanase yang dihasilkan oleh T5a1 yang meliputi optimasi pemekatan enzim menggunakan ammonium sulfat, pH optimum, suhu optimum, kestabilan enzim terhadap suhu dan pengaruh ion logam terhadap aktivitas enzim.

\section{BAHAN DAN METODE}

\section{Isolat Bakteri}

Bakteri kitinolitik diisolasi dari terasi yang diambil dari Sidoarjo, Jawa Timur.

Dari hasil skrining pada media padat yang mengandung koloidal kitin didapatkan 11 isolat yang positif menghasilkan enzim kitinolitik. Selanjutnya pada hasil skrining pada media cair, T5a1 diketahui menghasilkan kitosanase dengan aktivitas yang lebih tinggi (Zilda \& Chasanah, 2005)

\section{Produksi dan Preparasi Enzim}

Untuk produksi kitosanase digunakan koloidal kitin sebagai penginduksi (Arnold \& Solomon, 1986).
Satu lop isolat T5a1 diinokulasikan ke dalam $50 \mathrm{ml}$ medium starter. Medium ini terdiri dari $0,1 \%$ $\mathrm{K}_{2} \mathrm{HPO}_{4}, 0,01 \% \mathrm{MgSO}_{4} .7 \mathrm{H}_{2} \mathrm{O}, 0,1 \% \mathrm{NaCl}, 0,7 \%$ $\left(\mathrm{NH}_{4}\right)_{2} \mathrm{SO}_{4}, 0,05 \%$ yeast extract dan $0,5 \%$ koloidal kitin. Kultur diinkubasikan selama 18 jam pada $37^{\circ} \mathrm{C}$ $100 \mathrm{rpm}$ dalam inkubator goyang. Sebanyak $7,5 \%$ $(\mathrm{v} / \mathrm{v})$ starter diinokulasikan ke $75 \mathrm{ml} \times 10$ medium produksi dengan komposisi yang sama dan diinkubasikan pada kondisi yang sama dengan produksi starter selama 24 jam. Kultur kemudian disentrifus pada $10000 \mathrm{rpm}$ dan suhu $4^{\circ} \mathrm{C}$ selama 10 menit. Supernatan dikonsentrasikan menggunakan amonium sulfat pada berbagai konsentrasi (30-80\%) dan selanjutnya disentrifus setelah didiamkan semalam pada $4^{\circ} \mathrm{C}$. Endapan dilarutkan dengan 15 $\mathrm{ml} 0,5$ buffer fosfat $\mathrm{pH} 7$ dan didialisis dengan buffer yang sama untuk menghilangkan sisa garam. Enzim siap untuk dikarakterisasi.

\section{Pengukuran Aktivitas Kitosanase}

Aktivitas kitosanase diukur berdasarkan metode yang dikembangkan oleh Yoon et al. (2003) dengan menggunakan kitosan larut air sebagai substrat (Chasanah, 2004) Preparasi sampel dilakukan dengan mencampur 100ml kitosan larut air, $100 \mathrm{ml}$ buffer fosfat $(\mathrm{pH} \mathrm{6})$ dan $100 \mathrm{ml}$ larutan enzim. Campuran diinkubasikan pada $37^{\circ} \mathrm{C}$ selama 30 menit kemudian dipanaskan pada $100^{\circ} \mathrm{C}$ selama 5 menit untuk inaktivasi enzim. Dua ratus mikroliter campuran ditambah $800 \mathrm{ml}$ akuades dan $1 \mathrm{ml}$ reagen Schales kemudian dipanaskan pada $100^{\circ} \mathrm{C}$ selama 15 menit setelah sebelumnya tabung reaksi ditutup dengan aluminium foil untuk menghindari penguapan selama pemanasan. Campuran disentrifus pada 10000 rpm suhu $4^{\circ} \mathrm{C}$ selama 10 menit kemudian supernatan diukur absorbansinya pada $\lambda=420 \mathrm{~nm}$. Satu unit aktivitas kitosanase didefinisikan sebagai jumlah enzim yang memproduksi $1 \mathrm{mmol}$ glukosamin per menit.

\section{Penentuan pH dan Suhu Optimum}

$\mathrm{pH}$ optimum reaksi enzim ditentukan pada suhu $37^{\circ} \mathrm{C}$ dan kisaran $\mathrm{pH} 5-9$ yaitu dengan menggunakan buffer sitrat pada kisaran $\mathrm{pH} 5-6$, buffer fosfat pada kisaran $\mathrm{pH}$ 6-8 dan buffer borat pada kisaran $\mathrm{pH}$ 8-9. Sementara untuk penentuan suhu optimum dilakukan pada $\mathrm{pH}$ optimum yang telah didapat pada penelitian sebelumnya dengan kisaran suhu $30-60^{\circ} \mathrm{C}$ (Zilda \& Fawzya, 2006)

\section{Stabilitas Terhadap Suhu}

Stabilitas enzim terhadap suhu ditentukan dengan cara menginkubasikan enzim pada suhu 30, 40 dan $50^{\circ} \mathrm{C}$ selama 15 sampai 200 menit. Pengukuran 
akktivitas enzim dilakukan setelah enzim didinginkan hingga mencapai suhu kamar (Zilda \& Fawzya, 2006).

\section{Pengaruh lon Logam}

Untuk menentukan pengaruh ion logam terhadap aktivitas enzim digunakan berbagai kation sebagai logam klorida termasuk kation divalen $\left(\mathrm{Mg}^{2+}, \mathrm{Mn}^{2+}\right.$, $\mathrm{Ca}^{2+}, \mathrm{Cu}^{2+}, \mathrm{Co}^{2+}, \mathrm{Zn}^{2+}$, dan $\mathrm{Ba}^{2+}$ ), kation monovalen $\left(\mathrm{NH}_{4}^{+}, \mathrm{K}^{+}\right.$dan $\left.\mathrm{Na}^{+}\right)$dan kation trivalen $\left(\mathrm{Fe}^{3+}\right)$ dengan konsentrasi akhir $1 \mathrm{mM}$. Enzim ditambahkan ke dalam campuran buffer, kitosan larut air dan larutan ion logam kemudian diinkubasikan selama 30 menit pada suhu optimum selanjutnya diinaktivasi pada suhu $100^{\circ} \mathrm{C}$. Sebagai kontrol, ion logam ditambahkan setelah inaktivasi (Zilda \& Fawzya, 2006)

\section{HASIL DAN BAHASAN}

Sampel terasi diambil dari Sidoarjo, Jawa Timur. Terasi ini dibuat dari rebon melalui proses fermentasi selama 3 hari. Rebon digiling dan disimpan semalam untuk proses fermentasi. Hari berikutnya hasil gilingan dijemur di bawah sinar matahari, kemudian digiling lagi dengan penambahan air. Proses ini diulang sebanyak 3-4 kali. Bahan baku rebon yang mengandung kitin sangat potensial sebagai sumber isolasi bakteri kitinolitik.

\section{Pengendapan dengan Amonium Sulfat}

Hasil dari pemekatan enzim memperlihatkan bahwa konsentrasi optimal amonium sulfat untuk mengendapkan enzim T5a1 adalah 50\% (Gambar 1) dengan aktivitas $0,52 \mathrm{U} / \mathrm{ml}$. Konsentrasi lebih dari $50 \%$ tidak efektif mengendapkan enzim karena aktivitasnya yang rendah walau masih terdeteksi sampai konsentrasi amonium sulfat $80 \%$. Karena itu, untuk karakterisasi, enzim dipekatkan menggunakan $50 \%$ amonium sulfat.

Zhu et al. (2003) menyatakan bahwa aktivitas kitosanase dari mikroorganisme yang sejauh ini telah dilaporkan adalah antara $0,1-1,1 \mathrm{U} / \mathrm{ml}$ dan biasanya kurang dari $0,5 \mathrm{U} / \mathrm{ml}$. Namun aktivitas yang tinggi $0,8 \mathrm{U} / \mathrm{ml}$ ditunjukkan oleh kitosanase yang dihasilkan Enterobacter sp. G-1 (Yamasaki et al., 1994) dan Bacillus circulans WL-12 dengan aktivitas enzim $1,1 \mathrm{U} / \mathrm{ml}$ (Mitsutomi et al., 1998). Kitosanase dari T5a1 menunjukkan aktivitas yang masih rendah. Ini mungkin disebabkan karena enzim yang digunakan masih dalam bentuk kasar. Selain itu, cara produksi menggunakan erlenmeyer mungkin mempengaruhi aktivitas enzim. Zhu et al. (2003) melaporkan bahwa kitosanase yang dihasilkan oleh Acinetobacter sp. strain C-17 memiliki aktivitas yang lebih tinggi ketika ditumbuhkan pada fermentor 3 liter dibandingkan dengan erlenmeyer $250 \mathrm{ml}$. Hal ini mungkin disebabkan, kondisi produksi menggunakan fermentor lebih terkontrol (suhu, $\mathrm{pH}$ dan aerasi) selama proses produksi.

\section{Pengaruh pH Terhadap Aktivitas Enzim}

Dari hasil penelitian diketahui bahwa $\mathrm{pH}$ optimum untuk aktivitas kitosanase yang dihasilkan oleh isolat T5a1 adalah 7 seperti terlihat pada Gambar 2. Jenis buffer berpengaruh pada aktivitas enzim. Aktivitas pada $\mathrm{pH} 6$ menggunakan buffer fosfat ternyata lebih

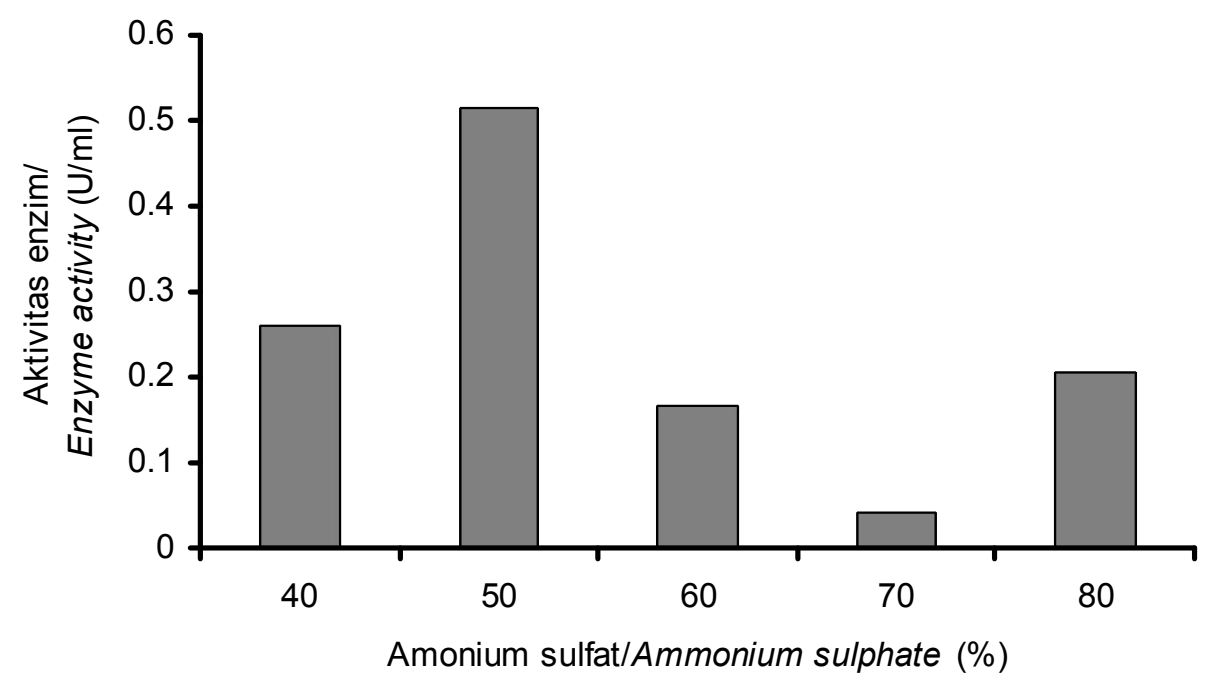

Gambar1. Pengaruh konsentrasi amonium sulfat terhadap aktivitas enzim. Figure 1. Effect of ammonium sulphate concentration on enzyme activity. 
tinggi dibandingkan dengan menggunakan buffer sitrat. Demikian pula pada $\mathrm{pH} 8$, penggunaan buffer borat ternyata memberikan aktivitas yang lebih tinggi dibandingkan menggunakan buffer fosfat. $\mathrm{pH}$ optimum 7 juga ditunjukkan oleh kitosanase yang dihasilkan Acinetobacter sp. C-17 (Zhu et al., 2003). Bacillus sp strain KCTC 0377BP menghasilkan kitosanase dengan pH optimum 4,0-6,0 (Choi et al., 2004) dan Streptomyces griceus HUT 6037 pada $\mathrm{pH}$ 6 (Toshiaki et al., 2003).

\section{Pengaruh Suhu terhadap Aktivitas Enzim}

Pengaruh suhu terhadap aktivitas kitosanase ditampilkan pada Gambar 3. Aktivitas enzim yang dihasilkan oleh isolat T5a1 meningkat seiring dengan meningkatnya suhu dan mencapai aktivitas tertinggi pada suhu $50^{\circ} \mathrm{C}$. Di atas suhu $50^{\circ} \mathrm{C}$ aktivitas mulai menurun dan tidak terdeteksi lagi pada suhu $70^{\circ} \mathrm{C}$. Kitosanase yang pernah dilaporkan mempunyai suhu optimum antara $37-70^{\circ} \mathrm{C}$. Zhu et al. (2003) melaporkan

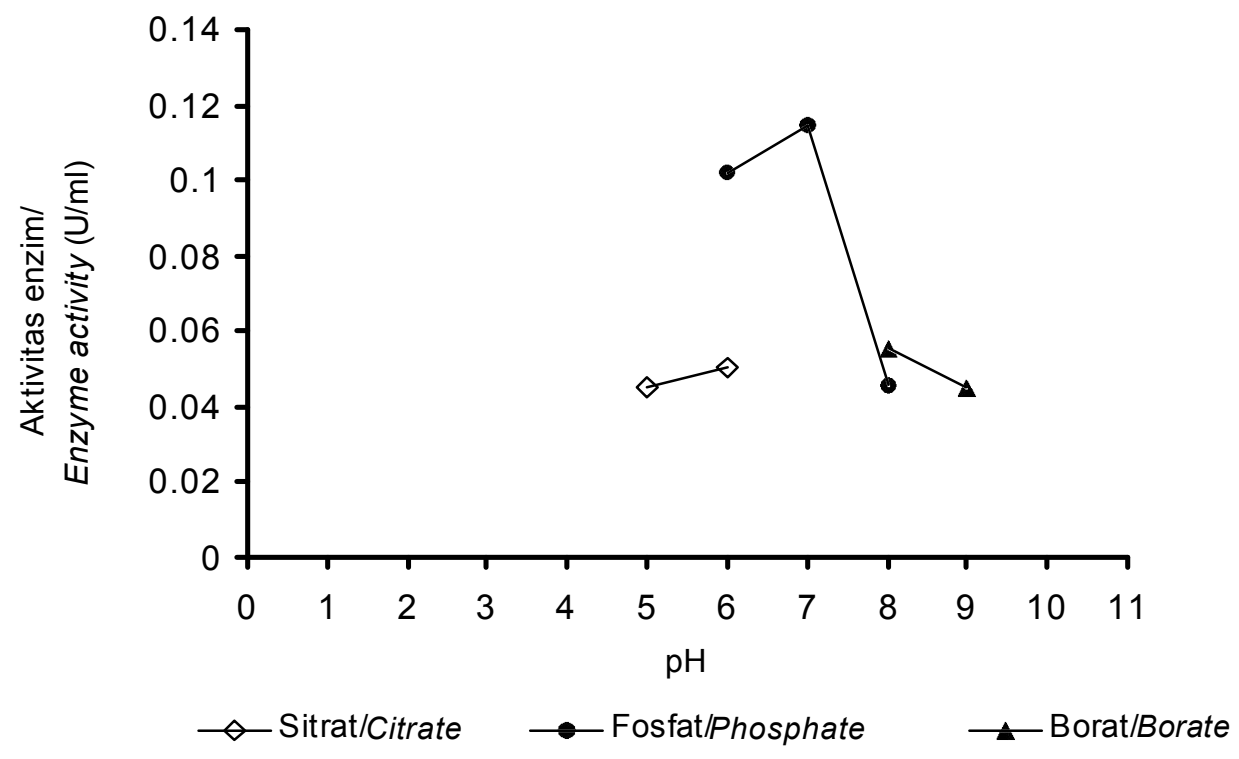

Gambar 2. Pengaruh pH terhadap aktivitas enzim kitosanase yang dihasilkan oleh T5a1.

Figure 2. Effect of pH on chitosanase activity produced by T5a1.

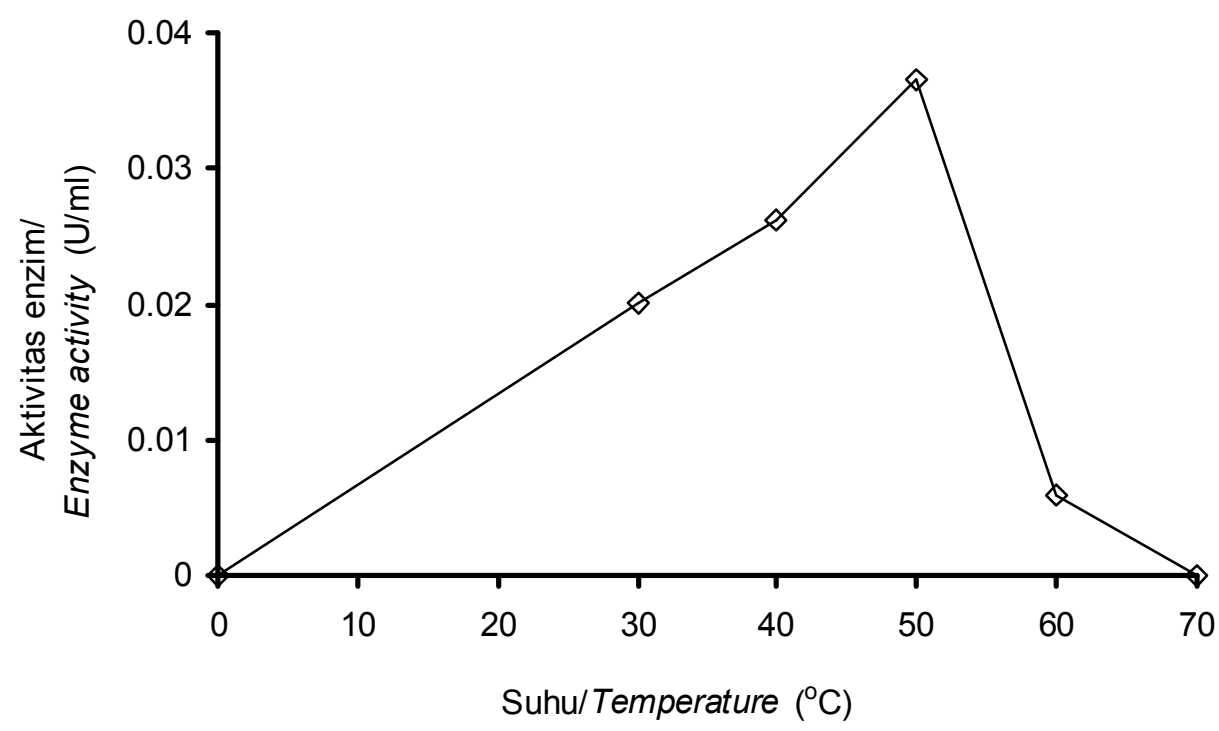

Gambar 3. Pengaruh suhu terhadap aktivitas kitosanase yang dihasilkan oleh T5a1.

Figure 3. Effect of temperature on chitosanase activity produced by T5a1. 


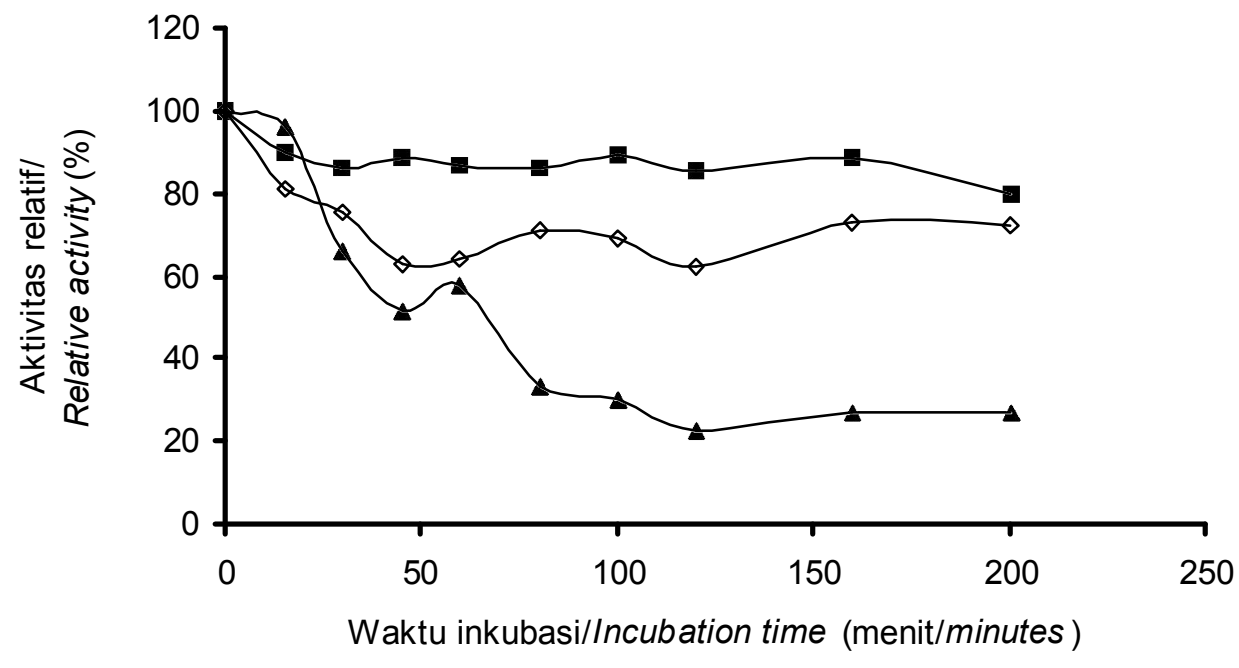

$$
\diamond 30^{\circ} \mathrm{C}=-40^{\circ} \mathrm{C} \simeq 50^{\circ} \mathrm{C}
$$

Gambar 4. Kestabilan kitosanase yang dihasilkan oleh T5a1 terhadap suhu.

Figure 4. Temperature stability of chitosanase produced by T5a1.

bahwa kitosanase yang dihasilkan oleh Acinetobacter sp. C-17 mempunyai suhu optimum $37^{\circ} \mathrm{C}$. Kitosanase lain dari beberapa mikroorganisme memberikan aktivitas maksimum pada suhu yang lebih tinggi seperti Bacillus sp strain KCTC $0377 \mathrm{BP}$ pada suhu $60^{\circ} \mathrm{C}$ (Choi et al., 2004), Streptomyces griceus HUT 6037 pada suhu $60^{\circ} \mathrm{C}$ (Toshiaki et al., 2003) dan B. circulans serta Bacterium sp. K-1 pada suhu $60^{\circ} \mathrm{C}$ (Somashekar \& Joseph, 1996).

\section{Stabilitas Enzim}

Pada percobaan sebelumnya sudah diketahui bahwa pada suhu $50^{\circ} \mathrm{C}$ enzim menunjukkan aktivitas

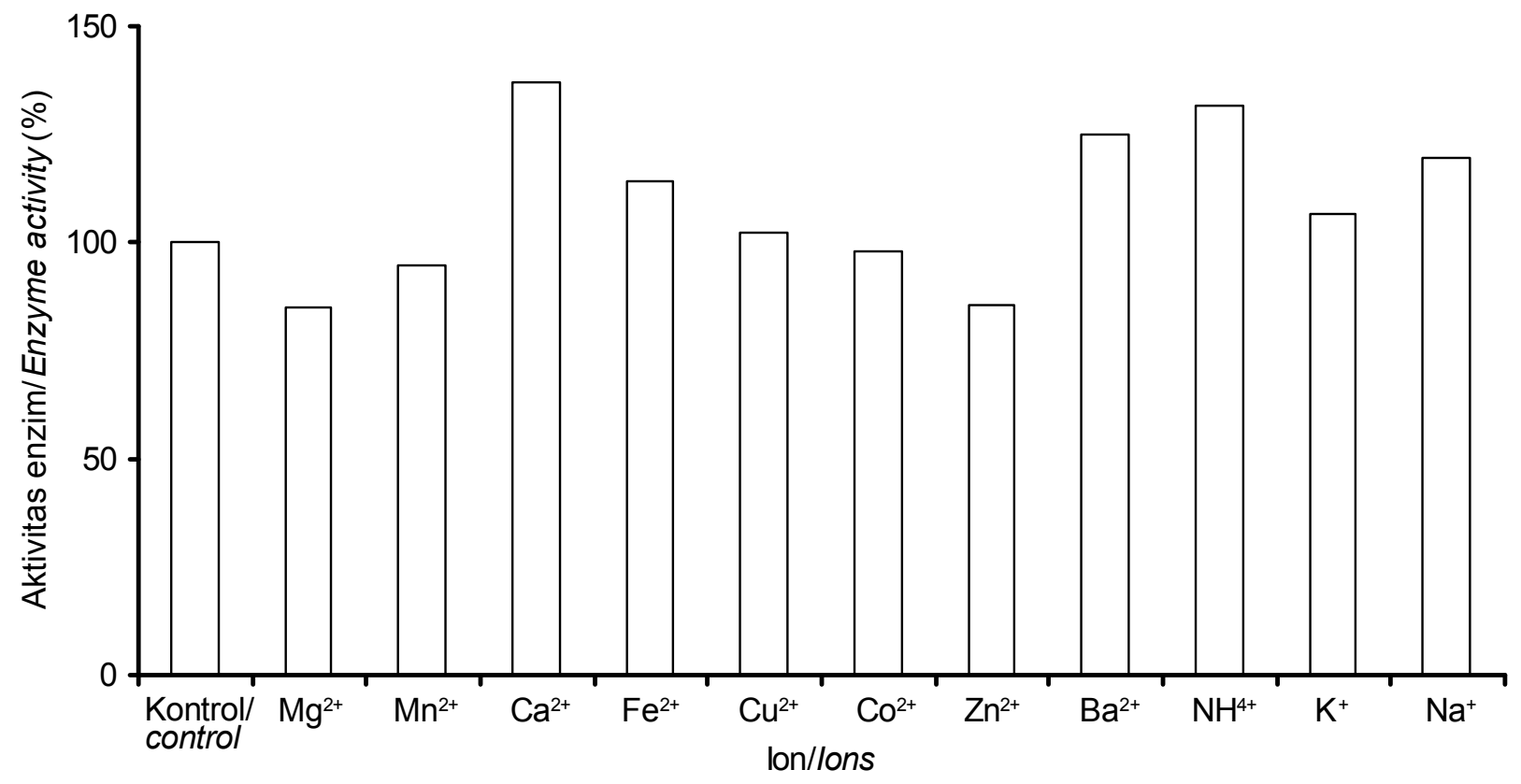

Gambar 5. Pengaruh ion logam terhadap aktivitas kitosanase yang dihasilkan oleh T5a1.

Figure 5. Effect of metal ions on chitosanase activity produced by T5a1. 
tertinggi (Gambar 4). Akan tetapi pada suhu tersebut enzim tidak stabil. Meskipun pada 15 menit pertama kehilangan aktivitas hanya $5 \%$, namun aktivitas enzim terus menurun dan hanya tersisa $50 \%$ setelah diinkubasikan selama 45 menit. Kitosanase yang dihasilkan oleh isolat T5a1 justru stabil pada suhu $40^{\circ} \mathrm{C}$. Aktivitasnya hanya berkurang $15 \%$ sejak inkubasi 15 menit sampai 160 menit. Walaupun pada suhu $30^{\circ} \mathrm{C}$ enzim juga cenderung stabil selama lebih dari 200 menit, namun sebenarnya enzim sudah kehilangan aktivitasnya sebesar kurang lebih $20 \%$ setelah 15 menit inkubasi. Poedjiati (1994) menyatakan bahwa kenaikan suhu dapat menyebabkan proses denaturasi enzim dan apabila ini terjadi maka bagian aktif enzim akan terganggu dan kecepatan reaksinya akan menurun.

\section{Pengaruh Ion Logam Terhadap Aktivitas Enzim}

Pengaruh ion logam $\mathrm{Mg}^{2+}, \mathrm{Mn}^{2+}, \mathrm{Ca}^{2+}, \mathrm{Fe}^{3+}, \mathrm{Cu}^{2+}$, $\mathrm{Co}^{2+}, \mathrm{Zn}^{2+}, \mathrm{Ba}^{2+}, \mathrm{NH}_{4}^{+}, \mathrm{K}^{+}$dan $\mathrm{Na}^{+}$) terhadap aktivitas kitosanase diukur pada konsentrasi akhir $1 \mathrm{mM}$. Seperti terlihat pada Gambar 5, ion $\mathrm{Mg}^{2+}, \mathrm{Zn}^{2+}$ hanya sedikit menghambat dengan menurunkan aktivitas enzim sampai $15 \%$. Pengaruh tertinggi diberikan oleh ion $\mathrm{Ca}^{2+}$ yang meningkatkan aktivitas sampai $37 \%$. Choi et al., (2004) melaporkan bahwa kitosanase yang dihasilkan oleh Bacillus sp. strain KCTC 0377BP aktivitasnya menurun sampai $69 \%$ dengan penambahan $\mathrm{Mn}^{2+}$.

\section{KESIMPULAN}

Konsentrasi ammonium sulfat optimum untuk pemekatan enzim adalah $50 \%$. Enzim mempunyai aktivitas optimum pada $\mathrm{pH} 7$. Meskipun enzim menunjukkan aktivitas tertinggi pada suhu $50^{\circ} \mathrm{C}$ tetapi lebih stabil pada suhu $40^{\circ} \mathrm{C}$. Dari hasil penelitian diketahui bahwa tidak satupun dari ion logam yang diujikan dapat meningkatkan aktivitas enzim lebih dari $37 \%$.

\section{DAFTAR PUSTAKA}

Alfonso, C., Martinez, M. J. and Reyes, F. 1992. Purification and properties of two endo-chitosanases from Mucor roxii implicated in its cell wall degradation. FEMS Microbiol. Lett. 95:187-194.

Arnold, L.S. and Solomon, N.A. 1986. Manual of Industrial Microbiology and Biotechnology. American Society for Microbiology., Washington DC.

Bocher, I., Dupuy, A., Vidal, P., Neugebauer, W.A. and Brzezinski, R. 1992. Purification and characterization of chitosanase from Streptomyces N174. Appl. Microbiol. Biotechnol. 38: 188-193.

Bosso, P., Defaye, J., Domart, A., Gadelle, A. and Pedersen, C. 1986 . The behavior of chitin towards anhydrous hydrogen fluoride. Preparation of $b-(1-$ 4)-linked 2-acetamido-2-deoxy-D-glucopyiranosyl oligosaccharides. Carbohydr.Res.156: 57-68.

Chasanah, E. 2004. Characterization of Chitosanase of Bacillus Licheniformis MB-2 Isolated from Manado Hot Spring Water. Dissertation. Bogor Agricultural University.

Cheng, C.Y. and Li, Y.K. 2000. An Aspergillus chitosanase with potential for large-scale preparation of chitosan oligosacharides Biotechnol. Appl. Biochem. 32: 197203.

Chiang, C.L., Chang, C.T. and Sung, H.Y. 2002. Purification and properties of chitosanase from a mutant of Bacillus subtilis IMR-NK1. Enzyme and Microbial Technology. 32: 260-267.

Choi, Y.J., Kim, E.J., Piao, Z., Yun, Y. C. and Shin, Y.C. 2004. Purification and characterization of chitosanase from Bacillus sp. Strain KCTC 0377BP and its application for the production of chitosan oligosaccharides. J. Appl. Environ. Microbiol.. 70: 4522-4531.

Fenton, D.M. and Eveleigh, D.E. 1981. Purification and mode of action of a chitosanase from Penicillium islandicum. J. Gen. Microbiol. 126:151-165.

Hadwiger, L., Ogawa, J.L. and Kuyama, H. 1994. Chitosan polymer sizes effective in inducing phytoalexin accumulation and fungal suppression are verified with synthesized oligomers. Mol. Plant. Microbe Interact. 7: 531-533.

Hedges, A. and Wolfe, R.S. 1974. Extracellular enzyme from Myxobaxter AL-1 that exhibit both $b-1,4$ glucanase and chitosanase activities. J. Bacteriol., 120: 844-853.

Hirano, S. 1988. Production and application of chitin and chitosan in Japan In Skjak-Braek, G., Anthonsen, T. and Sandford P. (eds.). Chitin and Chitosan . Eselvier Applied Science, London, United Kingdom. p. 37-43

Jeon, Y.J. and Kim, S.K. 2000. Potential immuno stimulating effect of antitumoral fraction of chitosan oligosaccharides (Abstract). The Korean Society for Chitin and Chitosan Department of Agricultural. Dongguk University, Gyungju. Korea. 6(4).

Jeong, Y.W., Kim, K.S., Joh, J.Y., Park, J.C., Lee, J.C., Yoo, K., Kim, J.W., Chang, S.J., Baek, W.K. and Seong, C. J.W. 2000. Chitosan oligosaccharides inhibit HL-60 cell growth through induction of apoptosis (Abstract). The Korean Society for Chitin and Chitosan Department of Agricultural. Dongguk University, Gyungju. Korea. 5(2).

Kendra, D.F., Cristian, D. and Hadwiger, L.A. 1989. Chitosan oligomers from Fusarium solani/pea interaction. Chitinase /b-glucanase digestion of sporeling and from fungal wall chitin actively inhibit fungal growth and enhance disease resistance. Phisiol. Mol. Plant Pathol., 35: 215-230.

Kendra, D.F. and Hadwiger. L.A. 1984. Characterization of the smallest chitosan oligomer that is maximally antifungal to fusarium solani and alicits pisatin formation in Pisum sativum. Exp. Mycol. 8: 276-281.

Kendra,Y.J. and Kim, S.K. 1998. Bioactivities of chitosan oligosacharides and their derivatives in Abstract of 
Asia Pasific Chitin and Chitosan Symposium, $64 \mathrm{pp}$ Kilung, Taiwan.

Kim, S.K., Jeon Y.J. and Zan, H.C. 2000. Antibacterial effect of chitooligosaccharides with different molecular weight prepared using membrane bioreactor $(A b$ stract). The Korean Society for Chitin and Chitosan Department of Agricultural. Dongguk University, Gyungju. Korea. 5(1).

Kim, W.S., Choi, C., Jang, M.K., Kim, S.H., Kim, M.Y. and Nah, J.W. 2002. Preparation of microspheres using water soluble and low molecular weight chitosan (Abstract). The Korean Society for Chitin and Chitosan Department of Agricultural. Dongguk University, Gyungju. Korea. 6(4).

Kurakake, M., Yo, U.S., Nakagawa, K., Sugihara M. and Komaki. T. 2000. Properties of chitosanase from Bacillus cereus S1. Current Microbiol. 40: 6-9.

Mitsutomi, M., Isono, M., Uchiyama, A., Nikaidou, N., Ikegami, T. and Watanabe, T. 1998. Chitosanase activity of the enzyme previously reported as b-1,31,4-glucanase from Bacillus circulans WL-12. Biosci. Biotechnol. Biochem. 62: 2107-2114.

Nam, M.Y., Yun, H. S., Kim, S.K., Kim, C.H. and Nam, K.S. 1999. Inhibitory effect of chitosan oligosaccharides on the growth of tumor cells (Abstract). The Korean Society for Chitin and Chitosan Department of Agricultural. Dongguk University, Gyungju. Korea. 4(4).

Nam, M.Y., Shon, Y.H., Kim, S.K., Jeong, T.R. and Nam, K.S. 2000. Chemopreventive potential of chitosan oligosaccharides (Abstract). The Korean Society for Chitin and Chitosan Department of Agricultural. Dongguk University, Gyungju. Korea. 5(2).

Nogawa,M., Takahashi, H., Kashiwagi, A., Ohshima, K., Okada, H. and Morikawa, Y. 1998. Purification and characterization of exo-b-D-glucosamidase from a cellulolytic fungus, Trichoderma reesei PC-3-7. Appl. Environ. Microbiol., 64:890-895.

Omumasaba, C.A., Yoshida, N., Sekiguchi, Y., Kariva, K. and Ogawa, K. 2000. Purification and some properties of novel chitosanase from Bacillus subtilis $\mathrm{KH} 1$. J. Gen. Appl. Microbiol. 46: 19-27.

Park, J.K., Shimono, K., Ochiai, N., Shigeru, K., Kurita, M., Ohta, Y., Tanaka, K., Matsuda, H. and Kawamukai, M. 1999. Purification, characterization, and gene analysis of chitosanase (Cho A) from Matsubacter chitosanotabidus 3001. J. Bacteriology., Nov.: 66426649.

Poedjiati, A. 1994. Dasar-dasar Biokimia. UI-Press. 472 $\mathrm{pp}$.

Putro, S. 1982. Study of Suitability of Chitinolastic Microorganisms for Shrimp Waste for Fermentation. Dissertation. University of Washington. 339 pp.

Sakai, K., Katsumi, R., Isobe, A. and Nanjo, F. 1991. Purification and hydrolytic action of chitosanase from Norcardia orientalis. Biochim. Biophys. Acta. 1079: 65-72.

Sanford, P.T. 2003. Advances in Chitin Science. Vol VI (Varum, KM, Domard, A and Smidsrod, O. (eds.). Trondheim, Norway.

Seino, H., Tsuduka, K. and Shimasue, Y. 1991. Properties and action pattern of chitosanase from Bacillus sp. P1-7S. Agric. Biol. Chem. 55: 2421-2423.

Shahidi, F., Arachi, J.K.V. and Jeon, Y.J. 1999. Food applications of chitin and chitosans. Food Sci. Techn. 10: 37-51.

Shimosaka, M., Fukumori, Y., Zhang, X.Y., He, N.J., Kodaira, R. and Okazaki,M. 2000. Molecular cloning and characterization of a chitosanolitic bacterium Burkholderia gladioli strain CHB101. Appl. Microbiol. Biotechnol. 54: 354-360.

Shimosaka, M., Nagawa, M., Ohno, Y. and Okazaki, M. 1993. Chitosanase from the plant pathogenic fungus, Fusarium solani f. sp. phaseoli : purification and some properties. Biosci. Biotechnol. Biochem. 57: 231-235.

Somashekar, D. and Joseph, R. 1996. Chitosanasesproperties and applications. Bioresource Technology 55: 35-45.

Toshiaki T., Kazuko, M., Tamo, F. and Masaru, M. 2003. Novel chitosanase from Streptomyces griseus HUT 6037 with Transglycosylation Activity. Biosci. Biotechnol. Biochem. 67(2): 354-364.

Tokoro,A., Tatewaki, N., Suzuki, K., Mikami, T., Suzuki, S. and Suzuki, M. 1988. Growth inhibitory effect of hexa-N-acetylchitohexaose and chitohexaose against Meth-A solid tumor. Chem. Pharm. Bull. 36: 784-790.

Uria, A.R. and Chasanah, E. 2005. Chitosanase and chitinase from microorganism associated with marine sponges. Proceeding of 9 th Asian Food Conference. Jakarta.

Yamasaki, Y., Hayashi, I., Ohta, Y., Nakagawa, T., Kawamukai, M. and Matsuda, H. 1993. Purification and mode of action of chitosanolitic enzyme from Enterobacter sp. G-1. Biosci. Biotechnol. Biochem. 57: 444-449.

Yamasaki, Y., Ohta, Y., Park, J.G., Nakagawa, T., Kawamukai, M. and Matsuda, H. 1994. Induction of the enzymes that degrade chitin and chitosan from Enterobacter sp. G-1. Bull. Fac. Agric. Shimane Univ, 28: 107-117.

Yoon, H.G., Kim, Y.H., Shin, D.H., Hong, B.S. and Cho, H.Y. 2003. Thermostable chitosanase from Bacillus sp. Strain CK4: Cloning and expression of gene and characterization of enzyme. Appl. And Env. Microbiol., p. 3727-3734.

Yoshihara, K., Hosokawa, J., Kuho, T., Nishiyama, M. and Koba, Y. 1992. Purification and properties of a chitosanase from Pseudomonas sp. H-14. Biosci. Biotechnol. Biochem. 56: 972-973.

Zhu, X.F., Wu, X.Y. and Dai, Y. 2003. Fermentation conditions and properties of chitosanase from Acinetobacter sp.-17. Biosci. Biotechnol. Biochem. 67(2): 284-290.

Zilda, D. S. and Chasanah, E. 2005. Screening of Chitinolitic Bacteria from Terasi. Paper presented at the $9^{\text {th }}$ of ASEAN Food Conference. Jakarta .

Zilda, D.S. and Fawzya, Y.N. 2006. Production and Characterization Chitosanase from Bacteria Isolated from Terasi. Paper presented at ASEAN Biochem. Sem. \& Workshop on Enzymes: Industrial and Medical Prospects, Feb. 6-7, 2006, Airlangga Univ. 
